\title{
OBSERVAÇÕES SOBRE O USO DE TEMAS QUÍMICOS SOCIAIS NO ATENDIMENTO EDUCACIONAL ESPECIALIZADO
}

\section{ARTIGO ORIGINAL}

MESSEDER, Jorge Cardoso ${ }^{1}$

MELLO, Ana Rita Gonçalves Ribeiro de ${ }^{2}$

FERREIRA, Caio Vitor ${ }^{3}$

SANTOS, Marcelo Augusto dos ${ }^{4}$

MESSEDER, Jorge Cardoso. Et al. Observações sobre o uso de temas químicos sociais no Atendimento Educacional Especializado. Revista Científica Multidisciplinar Núcleo do Conhecimento. Ano 05, Ed. 05, Vol. 10, pp. 05-33. Maio de 2020. ISSN: 2448-0959, Link de acesso: https://www.nucleodoconhecimento.com.br/educacao/temas-quimicos

\section{RESUMO}

A Química, embora não apareça como uma disciplina dos programas curriculares do ensino fundamental, apresenta-se nos conteúdos do Ensino de Ciências de forma mais intensa do que os docentes e estudantes possam perceber. Observa-se a distância entre a prática e a teoria, onde o licenciando em química não reflete sobre as possíveis metodologias que permeiam as práticas educativas de um professor de ciências, ao trabalhar no ensino fundamental. Quando se trata de práticas educativas

\footnotetext{
${ }^{1}$ Doutor e Mestre em Ciências. Químico Industrial.

2 Licenciada em Educação Física, Especialista em Educação Especial, mestranda em Ensino de Ciências (PROPEC/IFRJ), docente de Educação Especial no município de Mesquita/RJ.

${ }^{3}$ Licenciando em Química.

${ }^{4}$ Licenciando em Química.
} 
relacionadas ao Ensino Inclusivo, tal distância é ainda maior. O objetivo desse trabalho foi possibilitar que licenciandos em Química, de um Instituto Federal, pudessem vivenciar como se dá a relação ensino-aprendizagem no ambiente do Atendimento Educacional Especializado (AEE). Devido à importância de conhecimentos sobre Ciência e Tecnologia com responsabilidade social, foram realizadas observações durante intervenções pedagógicas com temáticas químicas sociais para os alunos dos anos iniciais, alicerçadas nos estudos de Ciência, Tecnologia e Sociedade (CTS). Os resultados indicaram que os fenômenos observados ao longo do processo permearam a realidade dos sujeitos, que puderam se apropriar do conhecimento científico, com aquisição de comportamentos e atitudes para respostas e tomadas de decisões. Enfoques para o ensino fundamental, e para o ensino inclusivo, se fazem importantes nas estruturas curriculares das licenciaturas, e devem figurar na formação continuada do professor, que se inicia no período das graduações.

Palavras-chave: Ensino de ciências, ensino CTS, atendimento educacional especializado, temas químicos sociais.

\section{INTRODUÇÃO}

A legislação educacional brasileira reitera a importância no currículo escolar dos conhecimentos de natureza científica e tecnológica que devem ser trabalhados no ensino de ciências desde os anos iniciais.

De acordo com os estudos de Miriam krasilchik (2012), a inclusão do ensino de ciências nos currículos brasileiros, para faixas etárias mais novas, ocorreu apenas nos anos 70 do século passado, onde passou a fazer parte das estruturas curriculares do ensino infantil.

Entretanto, embora exista consenso acerca da importância deste componente curricular, a sua implementação no ensino fundamental constitui ainda um desafio. Muitos estudantes consideram que os conteúdos da área de ciências são abstratos, difíceis de serem compreendidos, e contribuem desse modo, para o fracasso no 
rendimento escolar. Esse discurso faz com que o ensino de ciências perca seu potencial educativo, e caia na aceitação dos discentes.

Muitos professores não consideram a necessidade de se ensinar ciências nos primeiros anos da educação básica brasileira, com alegação de que é um esforço improfícuo, e que não apresenta resultados significativos na relação ensinoaprendizagem (ESHACH, 2006). Juntamente com esse pensamento, muitos educadores acreditam que ensinar ciências do $1^{\circ}$ ano ao $5^{\circ}$ ano seja uma tarefa com alto grau de complexidade, aonde eles não se vêm preparados (DUCATTI-SILVA, 2005). Para contornar esse problema, Pizarro e Lopes Jr. (2015) inferem que se deva dar uma atenção à formação continuada dos professores, com foco nas práticas pedagógicas em Ciências (para qualquer modalidade de ensino).

Ao contrário do que se pensa, o professor que ensina ciências para crianças conta com ousadia participativa e a curiosidade dos infantes, qualidades que estimulam e facilitam e a ação docente. O que resta a este professor é saber aproveitar a vontade de investigação que é intrínseca aos pequenos. Mesmo sabendo-se da real necessidade do ensino de ciências nos anos iniciais, nossos professores ainda necessitam de novos recursos e tecnologias educativas, além do livro didático.

O ensino nos anos iniciais do ensino fundamental carece de atenção à criança nas reflexões amplas sobre Ciência e Tecnologia. Fabri e colaboradores (2014) entendem que não é suficiente ensinar conceitos, mas é precisa que a criança, desde pequena, comece a refletir sobre o que ouve em seu contexto social. E quando esse ensino destina-se às crianças com deficiências?

Entre 1996 e 2010 foi feito um estudo investigativo sobre quais os procedimentos e recursos de ensino dedicados aos alunos deficientes (NUNES; BRAUN; WALTER, 2011). Nessa pesquisa, os autores concluíram que a aprendizagem do aluno com deficiência ocorre de forma diferente a do aluno sem deficiência, não tomando por base "a deficiência", mas sim, pelo fato de que "o outro" não oferece possibilidades variadas para que esses alunos deficientes se desenvolvam e aprendam de acordo com suas necessidades. 
Contudo, durante a etapa de escolarização dos estudantes com deficiência na sala de aula comum, ou até mesmo no contexto vivenciado nos atendimentos nas salas de recursos, há uma atenção maior para desenvolvimento de competências e habilidades nos conteúdos disciplinares de português e matemática, como se esses conhecimentos fossem os únicos satisfatórios para a promoção dos seus desenvolvimentos e autonomias.

O ensino de ciências constitui uma ferramenta capaz de despertar para a educação científica, uma vez que cria oportunidades para que o aluno aprenda sobre plantas, animais, corpo humano, astronomia e, assim, vincule esse conhecimento às questões da vida cotidiana, onde conceitos de ciência e tecnologia se relacionam às questões ligadas à invenção, ao avanço e ao futuro. Com isso, o sujeito assume a responsabilidade de tomar atitudes diante de determinadas situações para a vida em sociedade (KRASILCHIK; MARANDINO, 2007).

Ensinar ciências aos alunos especiais é permitir-lhes a vivenciar circunstâncias onde são capazes de tomar atitudes diante de determinadas situações. Os diferentes seguimentos da sociedade (econômico, tecnológico, social, cultura, político), assim como as diversidades de bens tecnológicos, devem estar disponíveis para a possibilidade do posicionamento desses alunos especiais, não os excluindo da compreensão do mundo que os cerca, para que dessa forma, possam desenvolver valores na busca de qualidade de uma vida melhor. $O$ ensino de ciências, enquanto área do conhecimento, deve ser acessível a todo cidadão.

Considerando o ensino de ciências a partir de questões sociais, o presente estudo se configura relevante à medida que prioriza o ensino CTS (Ciência Tecnologia e Sociedade) como forma de entender algumas questões da química/ciências no mundo contemporâneo de maneira interdisciplinar. Além do que, CTS como uma abordagem que se centra na formação para a cidadania, tem a finalidade de entender a realidade à volta, pelo fato de que, mais cedo ou mais tarde, as disposições sobre ciência e tecnologia chegarão à vida de todos, onde, por sua vez, os cidadãos terão condições de entender e agir no mundo pelo conhecimento científico, contrapondo o senso comum (PALACIOS et al., 2003). 
Diante do exposto, o empenho nesta pesquisa foi para se responder a seguinte pergunta: temas sócio científicos, por meio da abordagem em CTS, podem ser usados em estratégias didáticas pelo professor do Atendimento Educacional Especializado $(\mathrm{AEE})$ ?

\section{A EDUCAÇÃO ESPECIAL: UM POUCO DE REFLEXÃO}

Em 2015, a Lei Brasileira de Inclusão - LBI, lei 13.146/2015, também chamada de Estatuto da Pessoa com Deficiência, contempla áreas de saúde, educação, trabalho, assistência social, esporte, previdência, transporte, entre outras, onde busca desassociar deficiência com incapacidade, de forma a estabelecer autonomia e capacidade dos cidadãos com deficiência para exercerem atos da vida civil em condições de igualdade com as demais pessoas (BRASIL, 2015).

Neste cenário em que, entrecruzam constantes mudanças políticas, sociais, econômicas, a escola vem delineando caminhos que propõem modificações curriculares para conceber estratégias a fim e as pessoas com necessidades educacionais especiais terem condições plenas para o exercício da cidadania.

Dentre os vários documentos emanados pelo Ministério da Educação não existe um específico que oriente os sistemas e ensino quanto a parâmetros curriculares para a educação especial, o que há, de fato, são orientações, diretrizes para que os sistemas de ensino garantam o acesso aos conteúdos básicos que a escolarização deve proporcionar a todos os indivíduos - inclusive àqueles com necessidades educacionais especiais.

O conjunto da Educação Básica deve se constituir em um processo orgânico, sequencial e articulado, que assegure à criança, ao adolescente, ao jovem e ao adulto de qualquer condição e região do País a formação comum para o pleno exercício da cidadania, oferecendo as condições necessárias para o seu desenvolvimento integral (BRASIL, 2001, p.20). 
Em termos históricos e culturais, para transformações mais efetivas e significativas, ainda são grandes os desafios em relação às práticas pedagógicas e à construção da aprendizagem, ainda que, o acesso desse alunado já tenha alcançado um percentual considerável, em que "aproximadamente $80 \%$ dos alunos com deficiência estão inseridos no sistema educacional comum, segundo dados do censo escolar" (CORREIA; BAPTISTA, 2018, p.729).

A educação especial conseguiu avanços significativos no processo de escolarização dos alunos desde a implementação da política nacional, em 2008; no entanto, investir nos pontos fortes e potencial de desenvolvimento desses alunos ainda representam desafios à equipe escolar, uma vez que a história dessas pessoas os rotulam como incapazes de frequentar ambientes regulares e classes comuns (CORREIA; BAPTISTA, 2018).

Portanto, para a efetivação da proposta de inclusão são necessárias estratégias curriculares, no sentido de que sejam realizadas as adequações necessárias, em termos de objetivos, conteúdos, metodologias, atividades, materiais, recursos, avaliação, etc. Também, é necessário o que o professor tenha capacidade para lidar com as diferenças, com as singularidades e a diversidade de todas as crianças, e não se prenda a um modelo de pensamento comum a todas elas.

Sendo assim, o foco de toda luta e movimento pró-inclusão é um limiar único: preparar o cidadão para viver e conviver com os desafios do dia a dia para a compreensão do mundo. Ainda tem-se um descrédito muito grande dos professores quanto à capacidade de o aluno com deficiência aprender, talvez por insegurança de lidar com as especificidades daquele aluno ou por medo de receber esse aluno em sua turma e Ihe causar certo desconforto. Por isso, "muitas vezes a falta de preparo e informação impede o professor de desenvolver uma prática pedagógica sensível às necessidades do aluno especial incluído" (PLETSCH, 2009, p. 148).

Outra questão muito debatida é a falta de preparo dos professores e demais profissionais da educação para lidar com a diversidade dos sujeitos com deficiência, onde os processos de formação inicial e continuada dão indícios de precariedade. 
Mesmo os cursos de licenciatura criando legislações que exigem o cumprimento de conteúdos e disciplinas para ações pedagógicas voltadas à diversidade, já se cria e se forma uma docência dicotômica: professores para o ensino comum e professores para o ensino regular. Daí em diante, criam-se representações sociais que não se diluem à medida que o docente ascende à sua atuação (GLAT, 2018). De acordo Glat (2018, p. 13) "os cursos de formação de professores ainda privilegiam uma concepção clássica, estática, do processo de ensino e aprendizagem, baseada em uma noção de desenvolvimento "normal" (diga-se, "saudável") e universal para todos os sujeitos".

Sobre esse ponto, Pletsch (2009) também chama atenção para os cursos de formação de professores, de forma que os órgãos responsáveis tenham a preocupação de formar o professor com o oferecimento de disciplinas e conteúdos para atender os alunos com necessidades especais, de forma que desempenhem, satisfatoriamente, sua atribuição de ensinar dentro de um contexto diverso, afinal, o maior desafio, nesse sentido, centra-se na necessidade de adotar medidas para que a condição da educação inclusiva desloque sua posição para uma prática pedagógica voltada à diversidade.

[...] podemos dizer que o professor deve valorizar a diversidade como aspecto importante no processo de ensino-aprendizagem. Além disso, necessita ser capaz de construir estratégias de ensino, bem como adaptar atividades e conteúdos, não só em relação aos alunos considerados especiais, mas para a prática educativa como um todo, diminuindo, assim, a segregação, a evasão e o fracasso escolar (PLETSCH, 2009, p. 149).

Benite; Benite, e Vilela-Ribeiro (2015) colocam que a necessidade de formar professores aptos a executar a tarefa de lidar com educandos especiais está entre os fatores determinantes do sucesso ou insucesso da Educação Inclusiva. Recursos para otimizar o trabalho pedagógico do professor e a aprendizagem do alunos. Trabalhos esses que apontam a promoção da inclusão e da aprendizagem dos alunos com deficiência, mas, a verdade é que pouco tem sido o avanço nesse sentido. 
A despeito dessa situação, Lippe e Camargo (2010), relatam a conduta de uma professora de Ciências da sala de aula comum com alunos cegos, matriculados em turmas de $9^{\circ}$ ano na rede pública de ensino da região de Bauru, onde concluem que a inclusão ainda está muito aquém do que é preconizado. E com isso, apontam a necessidade de efetiva formação continuada de professores da sala regular que possuem alunos incluídos (nessa pesquisa, em especial, fazem referência à deficiência visual), a fim de criar maior diálogo com os professores especialistas do AEE, objetivando maior apoio ao processo de aprendizagem desses alunos, pois

a dificuldade do professor da educação básica é a falta de preparo/capacitação profissional, falta de infra-estrutura das escolas e escassez de materiais didáticos, bem como do conhecimento de uma forma de avaliação que seja adaptada às condições dos alunos com deficiências (LIPPE; CAMARGO, 2010, p. 6).

\section{O ATENDIMENTO EDUCACIONAL ESPECIALIZADO (AEE)}

Esse serviço foi instituído pela Política Nacional de Educação Especial na Perspectiva da Educação Inclusiva ${ }^{[5]}$, em 2008, quando se inicia a ampliação de políticas públicas no sentido de criar/alterar conceitos, legislações, serviços e práticas pedagógicas para complementar e/ou suplementar a formação dos alunos com vistas à autonomia e independência na escola e fora dela (BRASIL, 2008).

O Atendimento Educacional Especializado $(\mathrm{AEE})^{[6]}$ é ofertado principalmente nas Salas de Recursos Multifuncionais (SRM) ${ }^{[7]}$, e foi criado como serviço de atendimento pedagógico especializado ao público alvo da Educação especial.

Partindo de uma avaliação inicial, o professor do AEE busca conhecer o aluno, suas possibilidades, sua família, para que, da melhor forma construa um documento que promova as adequações necessárias e possíveis para uma aprendizagem eficiente. É um planejamento pedagógico é individual e especializado à medida que busca desenvolver, aperfeiçoar no aluno, a partir de sua especificidade, sua capacidade de acesso ao currículo regular e, consequentemente, à aprendizagem. Nessa trajetória, 
é necessário que o trabalho pedagógico considere e se embase em vários aspectos, como: organização do espaço, materiais, recursos disponíveis, metodologias, estratégias adotadas, apoio familiar, entre outros, de maneira a superar as barreiras e promover a participação de todos.

\section{ESTUDOS DE CIÊNCIA, TECNOLOGIA E SOCIEDADE (CTS): OPÇÃO PARA A PESQUISA}

Os ECTS ${ }^{[8]}$ (Estudos de Ciência, Tecnologia e Sociedade) tomam importante rumo a partir de 1970 quando se busca uma resposta para contrapor a ideia e sentimento que imperava desde o início do século XIX até o pós Segunda Guerra Mundial, de que o desenvolvimento científico e tecnológico era somente bem-estar e redenção dos males da humanidade (VON LINSINGEN, 2007).

Portanto, Von Linsingen (2007), discorre que é num momento de crise, catástrofes ambientais, que esse sentimento salvacionista perde força, quando se iniciam e estabelecem condições para uma nova forma de enxergar a interação ciência, tecnologia e sociedade. Vários episódios ocorridos no século passado já deixavam a sociedade contraposta acerca dos pontos positivos e negativos da C\&T (ciência/tecnologia), como por exemplo, a devastação que ocorreu em Nagasaki e Hiroshima por conta das explosões das bombas atômicas, a descoberta do buraco na camada de ozônio, provavelmente ocasionada por ações antrópicas, os problemas decorrentes da poluição atmosférica em varias parte do mundo, os vastos derramamentos de óleo e suas consequências ambientais, acidentes com usinas nucleares, como o caso de Chernobyl, em 1986 (BAZZO, 2002).

Com o advento da tecnologia são cada vez mais contundentes os discursos que professam a ação incisiva da tecnologia no progresso da sociedade, onde a supremacia tecnológica é enaltecida como fonte da subsistência humana. No entanto, no mundo globalizado há necessidade de entender os diversos contextos que recebem o reflexo do processo tecnológico avassalador, que, em sua essência traz consequências que devem ser julgadas por toda a sociedade (BAZZO, 2002). 
Portanto, educar para a cidadania, implica no questionamento à ordem da sociedade capitalista, em que valores econômicos sobrepõem aos demais valores; valores esses ligados às necessidades humanas por estarem "vinculados aos interesses coletivos, como os de solidariedade, de fraternidade, de consciência do compromisso social, de reciprocidade, de respeito ao próximo e de generosidade" (SANTOS; MORTIMER, 2000, p.114).

Ao serem incluídos no currículo, a proposta é que os Aspectos Sociocientíficos (ASC) sejam trabalhados dentro de uma característica controversa, em que seja possível introduzir perguntas, onde suscitem debates dentro de um processo argumentativo. Nessa linha de pensamento, Ratcliffe (1998 apud SANTOS; MORTIMER, 2009) propõe categorias para se trabalhar o ensino de ciências por meio da abordagem de ASC, os quais são:

(1) relevância, com o objetivo de estimular os alunos a relacionar o ensino de ciências aos problemas do cotidiano de modo a desenvolver responsabilidade social; (2) motivação do aluno para as aulas de Ciências; (3) comunicação e argumentação, de modo a desenvolver no aluno a capacidade de se expressar com argumentos (4) análise, aprofundar o nível de exigência do cognitivo do aluno; (5) compreensão, auxiliar o aluno a compreender conceitos científicos e a natureza da ciência. (ibid., p. 192).

Segundo Walter Bazzo (2002), dentre as diversas concepções CTS, podem ser destacadas a europeia e a norte-americana, que são na verdade, as que deram origem a esse pensamento. Enquanto a norte-americana enfatiza a tecnologia, a europeia prioriza os fatores sociais, marcados por questões sociológicas, psicológicas e antropológicas, mas ambas sempre apostaram na formação básica de seus cidadãos através da alfabetização da ciência e tecnologia, ampliando seus esforços em esclarecer sobre as repercussões advindas do desenvolvimento científico e tecnológico. 


\section{DESENVOLVIMENTO}

Os sujeitos da pesquisa foram alunos do AEE da Escola Municipal Irena Sendler, residentes na Baixada Fluminense (RJ), matriculados no ensino fundamental I e II, no $2^{\circ}, 3^{\circ}, 4^{\circ}, 5^{\circ}, 6^{\circ}, 7^{\circ}$ e $8^{\circ}$ anos, do no ano de 2019, o que incluiu alunos com deficiência, transtorno do espectro autista e transtornos funcionais específicos. As intervenções pedagógicas foram conduzidas por dois licenciandos bolsistas do Programa Institucional de Bolsas de Iniciação Científica (PIBIC), juntamente com a professora regente, pesquisadora integrante do grupo de pesquisa, e uma das autoras deste artigo. Os dois alunos do $A E E$, aqui mencionados, são apresentados por nomes fictícios e ambos com características de transtorno funcional específico bem próximas, de forma que demonstram lentidão no processo de raciocínio lógico e abstração do pensamento, o que resulta em extrema dificuldade no processo ensino e aprendizagem; ambos sem autonomia do processo de leitura e escrita, onde precisam de apoio constante nas atividades que exploram e contemplam o letramento de matemática e português e, ainda, apresentam histórico de retenção escolar. Constam de João, de 9 anos, aluno matriculado no $3^{\circ}$ ano; e Alisson, 15 anos, aluno do 6을.

A coleta de dados se constituiu dos relatos dos alunos ao longo da pesquisa, com base nas intervenções, nas anotações realizadas pelos dois bolsistas do PIBIC, registros em caderno de bordo, fotos e vídeos juntados pela pesquisadora (professora regente da SRM) sobre as observações da interação pesquisadores e pesquisado, assim como, a descrição do comportamento do sujeito diante das intervenções pedagógicas. Ao longo do artigo, a fala dos pesquisadores é codificada pela letra "P", para fins de identificação e maior compreensão dos diálogos.

Para este estudo, além dos temas químicos sociais, os Parâmetros Curriculares Nacionais de Ciências Naturais, também embasaram a escolha pelos conteúdos a serem desenvolvidos. O objetivo das Ciências Naturais é "apontar metas de qualidade que ajudem o aluno a enfrentar o mundo atual como cidadão participativo, reflexivo e autônomo, conhecedor de seus direitos e deveres" (BRASIL, 1997, p. 5). Ainda, o documento preconiza o conhecimento com o meio ambiente, com a saúde, questões 
éticas relativas a direitos humanos, assuntos vinculados à sexualidade, à dignidade e à solidariedade ao ser humano.

Por conseguinte, o presente trabalho apresenta a observação das concepções e o posicionamento dos alunos a partir de atividades em ensino de Ciências, frente aos impactos da C\&T sobre a sociedade, com base no ensino CTS.

Cada tema foi escolhido conforme emergência e relevância no contexto do estudante, referenciado à interdisciplinaridade, cujos conteúdos envolveram diversos saberes relacionados aos aspectos sociais, econômicos, culturais, o que possibilitou uma ampla discussão relacionada à ciência, à tecnologia e à sociedade.

Cada tema que foi desenvolvido teve a programação de cinco blocos, onde cada bloco teve a duração de, aproximadamente, 50 minutos.

A articulação entre os temas contou com atividades de exploração de livros da literatura infanto-juvenil, vídeos, reportagens, explicações expositivas, diálogos, atividades escritas, atividades de pintura, simulações e jogos pedagógicos, foram utilizadas também, algumas atividades do Produto Educacional elaborado por Oliveira (2017), às quais estiveram em consonância com a proposta da referida pesquisa, e, quando necessário, foram reproduzidas, dadas as adaptações, se necessário.

\section{JOGOS E BRINCADEIRAS: RECORTE TRAZIDO PARA ESTE ARTIGO}

A escolha por explorar jogos e brincadeiras enquanto estratégias didáticas deriva-se das peculiaridades que essas atividades provocam nas crianças, mesmo porque o desenvolvimento da criança gira em torno do ato do brincar e, desse processo acontece a formação e construção do ser humano. "Ensinar por meio da ludicidade é considerar que a brincadeira faz parte da vida do ser humano e que, por isso, traz referenciais da própria vida do sujeito" (RAU, 2007, p.31).

De acordo com Kishimoto (2008) é importante que o professor tenha claro o que se pretende ensinar dentro do processo de ensino aprendizagem, já que o jogo enquanto recurso pedagógico tem duas funções: onde a primeira seria a função lúdica, que parte 
da escolha voluntária do aluno, em que sua vivência traz o prazer, a alegria. $E$, em segundo, a função educativa, com o objetivo de desenvolver os conhecimentos, a compreensão de mundo pelo aluno, sob a ação do professor.

Como recorte para este artigo, trouxemos os resultados obtidos com o uso de jogo da memória. De acordo com Kiya (2014), o jogo da memória é um jogo de regra simples que pode ser jogado por pessoas de todas as idades, cujo objetivo é a memorização das imagens de forma rápida, desenvolvendo e aperfeiçoando o raciocínio, culminando com o desenvolvimento de habilidades como: discriminação visual, atenção, concentração e memorização.

Com o apoio desse conceito, as intervenções realizadas buscaram, por meio do jogo da memória, exigir dos alunos João ( $3^{\circ}$ ano) e Alisson (6ำ ano) a memorização das imagens, o raciocínio, visto que são alunos ainda não autônomos no processo de leitura e escrita e, portanto, atividades com uso de imagens dão resultados mais positivos, pois esses alunos conseguem memorizar melhor com a exploração de imagens. Dessa forma, foi elaborado um jogo sobre os tipos de poluição (poluição visual, poluição sonora, poluição do ar, poluição da água, poluição do solo), onde os alunos puderam entender e visualizar, de forma concreta, o conceito dos diferentes tipos de poluição.

Com isso, os jogos desenvolvidos junto com os alunos, tiveram ainda, como objetivo, a explorar conceitos, como por exemplo, tipos de poluição, dentro do tema meio ambiente, explorar os órgãos e sentidos sensoriais e, de modo geral, motivar o aluno a internalizar o conhecimento científico para que se posicionasse de forma crítica e decisiva frente a determinadas situações.

\section{PERCEPÇÕES HUMANAS NO AMBIENTE: EU NO MUNDO}

Identificar com clareza e compreender a forma de perceber o mundo com base nos estímulos do meio é de relevância para o aluno, pois significa falar de, como ele, enquanto ser humano age e reage aos mecanismos e processos intrínsecos e 
extrínsecos do ambiente, é falar das sensações agradáveis e desagradáveis, do ar contaminado e também da poluição sonora que tanto interferem no modo de vida dele.

Nesse tema, com elevado potencial interdisciplinar, é possível discutir questões da ciência e tecnologia, tanto relacionadas à área de ciências - Biologia, Química, Física - quanto assuntos de caráter social e cultural, como, marcas, propagandas, influência dos meios de comunicação, onde esses têm forte apelo e influência nos modos de vida, atitudes e comportamento das pessoas na sociedade.

Este artigo traz recortes das atividades desenvolvidas com dois alunos pesquisados dentro do tema "Lixo", em que os assuntos abordados visaram a conhecimentos científicos com aplicação à vida do cidadão, para que o mesmo seja capaz de compreender e transformar sua realidade.

\section{AS INTERVENÇÕES PEDAGÓGICAS}

Com o aluno João, do $3^{\circ}$ ano, dentre os assuntos abordados, em um dos encontros, foi desenvolvido o conteúdo sobre o destino do lixo, com a seguinte problematização: "Para onde vai seu lixo?". Os objetivos a serem alcançados visaram do conhecimento da rota do lixo à identificação dos diferentes tipos de materiais reciclados.

Nesse sentido, usou-se uma imagem ilustrativa das fases de descarte do lixo urbano, a fim de mostrar o processo de reciclagem, as cooperativas, os diversos tipos de lixo e todo processo de separação, limpeza e destino correto, de acordo com cada tipo, e também apresentar as duas categorias do lixo: o lixo seco composto por plástico, papel, metal, vidro, e o lixo úmido, que compreende os alimentos, restos de frutas e folhas.

Assim sendo, a partir do processo de contextualização e conceituação do conteúdo, houve as seguintes reflexões: "O lixo é uma coisa boa ou ruim? O que você faz para manter o meio ambiente agradável? Qual a importância de manter o meio ambiente limpo? Para onde vai o lixo da sua cidade? O que é Aterro Sanitário?". 
E então, como forma de avaliar a apropriação do conteúdo, a partir do entendimento do aluno, foi proposta uma atividade de releitura das fases de descarte do lixo por meio de desenhos (importante dizer que o aluno ainda não é autônomo no processo de leitura oral e escrita). Com isso, o aluno produziu seis slides ilustrativos e produziu uma televisão de material reciclado para servir de divulgação dos slides produzidos pela releitura da "Rota do lixo".

Com o aluno Alisson do $6^{\circ}$ ano, um dos assuntos desenvolvidos foi sobre as transformações físicas, geográficas ocorridas no ambiente, em consequências das atividades do homem no seu habitat. Dessa forma, a problematização foi: "Por que o homem modifica a natureza?".

Tomando como base os objetivos propostos de compreender o processo de mudança do espaço natural, e pesquisar fotos antigas e recentes do entorno da escola, a estratégia metodológica adotada constou da observação de fotos antigas e sair em passeio tirando fotos atuais desse mesmo entorno,

Dessa forma, cabe apontar as reflexões enquanto recursos para a contextualização do assunto: "Qual o resultado das ações humanas no meio ambiente? Por que você acha que se modificou tanto? Quem são os responsáveis pelas mudanças? Quais as coisas boas vindas com as mudanças? Quais as coisas ruins?".

Esse sujeito apresenta lentidão na sua capacidade de abstração e generalização, o que dificulta o processo de ensino e aprendizagem, no entanto, as atividades com maior êxito devem apresentar as características que dê significado para o aluno, com relação à realidade dele.

Sobre a atividade, foi proposta a tarefa de sair caminhando pelo entorno da escola observando os estabelecimentos, os diversos locais, casas, conversas com as pessoas, tirar fotos da proximidade da escola, de alguns locais e, após, realizar comparações com fotos antigas desse mesmo entorno (conseguidas junto ao setor de comunicação social, da prefeitura municipal de Mesquita). 
Assim sendo, para o desenvolvimento do enfoque CTS, há o respeito à ordem psicológica da aprendizagem conceitual, seleção e ordenação dos temas sociocientíficos, que são feitos considerando-se o grau de complexidade dos conteúdos científicos vinculados aos temas de acordo com o desenvolvimento cognitivo do aluno (MUNDIM; SANTOS, 2012).

Os alunos receberam uma situação-problema cotidiana para ser resolvida, e com isso, foi possível que eles recorressem, inicialmente, aos conhecimentos que já traziam e, à medida que recebiam informações, articulavam-nas às suas vivências, com observações, comparações, hipóteses, e então, modificaram seus conceitos.

\section{DISCUSSÃO DOS RESULTADOS}

Tomando como base documentos normativos do Ministério da Educação para as etapas da educação básica dentro da área de Ciências da Natureza, por exemplo, os Parâmetros Curriculares (PCN), de 1997, e a Base Nacional Comum Curricular (BNCC), ficam claros os objetivos das Ciências da Natureza dentro do ciclo escolar, que, dadas algumas especificidades de cada uma, é de levar o sujeito a compreender, interpretar o mundo e agir sobre ele para transformá-lo, por meio do acesso ao conhecimento científico natural, social e tecnológico (BRASIL, 2017).

Diante do exposto, há de se fazer considerações importantes associadas à modalidade da Educação Especial no que se refere às especificidades e nuances, visto existir aspectos e níveis diferentes para cada indivíduo voltados à sua condição especial.

Assim sendo, são apresentados alguns diálogos no contexto da pesquisa onde mostra o processo de envolvimento dos alunos na apreensão do conhecimento em ensino de Ciências.

A despeito disso, abaixo seguem recortes da fala do aluno João sobre o destino do lixo na atividade de releitura da "Rota do lixo", uma das estratégias propostas. 
João: O lixo que a gente faz vai para o aterro sanitário, vai para as fábricas, e também, outra parte, vai para a terra para virar adubo.

João: O papel encontrado no lixo foi levado pelo caminhão para a fábrica de reciclagem de papel.

João: Que limpe o lixo.

João: Porque senão todos morrem.

As falas do aluno João demonstram o entendimento dele sobre o processo de destino do lixo, com possibilidade de reciclagem e os riscos advindos pelo descarte impróprio, com a decisão do aluno de cuidar e zelar pela limpeza do entorno dele, como: colocação do lixo doméstico em local onde passa a coleta urbana.

A atividade proposta foi a criação de uma história a partir da de releitura do destino do lixo, em que envolveu a imaginação do aluno para criar a história dele sobre a rota do lixo. A realização dessa atividade exigiu do aluno João a ação de descrever e reproduzir como se processa o destino do lixo, mais precisamente, em sua redondeza. O trabalho uniu o potencial do aluno em opinar, imaginar, criar, onde apontou um fator positivo, que foi a resposta coerente dele diante da realidade retratada/representada. O trabalho consistiu na produção de uma televisão de materiais reciclados, como papelão, canudo de papelão, tampinhas plásticas de garrafa PET, associando possibilidades de reciclar, o que, justamente, tinha sido estudado. A figura 1 mostra a releitura da rota do lixo assimilada pelo aluno, dentro daquilo que Ihe foi mais significativo, com a produção de slides. 
Figura 1 - Releitura da rota do lixo por meio de uma sequência de slides.

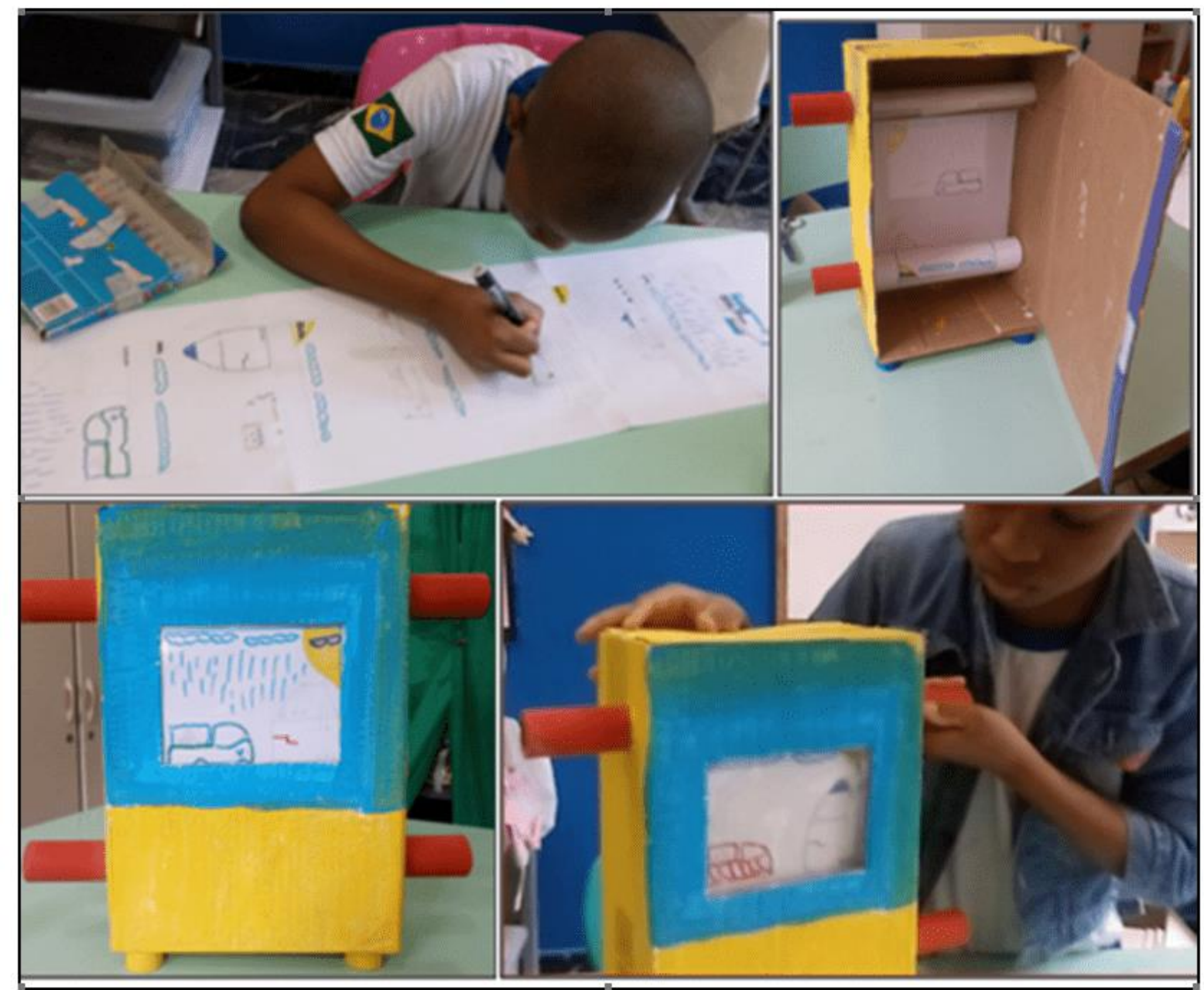

Fonte: arquivo de pesquisa.

A história criada pelo aluno João compôs-se de seis slides, ilustrados por ele, onde conta o que, de mais significativo foi assimilado por ele (figura 2), e pode ser visualizada na que recebeu do aluno o seguinte título: "Cuidando da natureza com a reciclagem". 
Figura 2 - Releitura da rota do lixo por meio de uma sequência de slides.

\section{CUIDANDO DA NATURE ZA COM A RECICLAGEM}

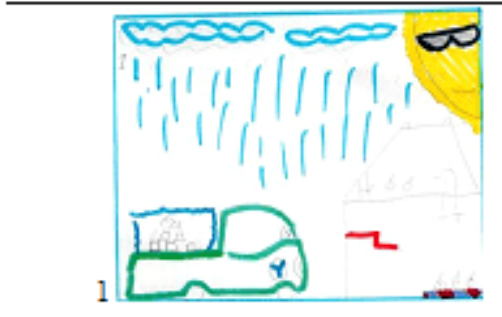

O lixo que a gente faz vai para o aterro sanitário, vai para as fábricas, e também, outra parte, vai para a terra para virar adubo. Era uma vez o caminhão de lixo que peg ou o lixo, esmag ou e levou para o aterro sanitário.

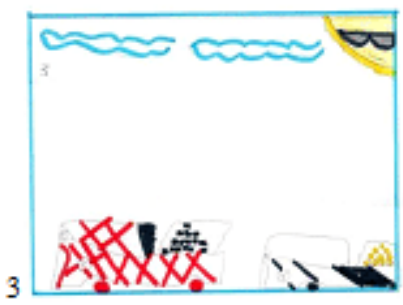

Dois caminhões foram recolher o lixo. Um foi para a loja de reciclagem de metal e o cutro foi para o aterro sanitário com coisas que não são aproveitadas.

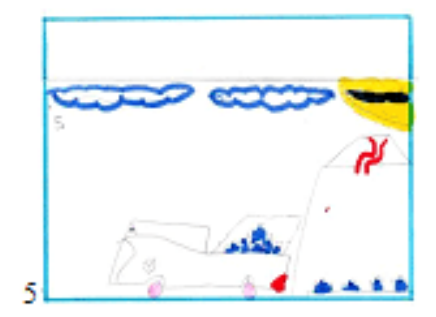

O plástico também virou galão, que serve para pôr água, e o galão com água volta para o supermercado vender.

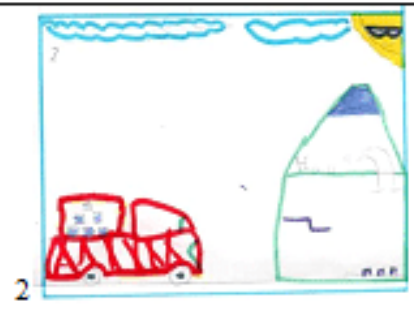

O papel encontrado no lixo foi levado pelo caminhão para a fábrica de reciclagem de papel.

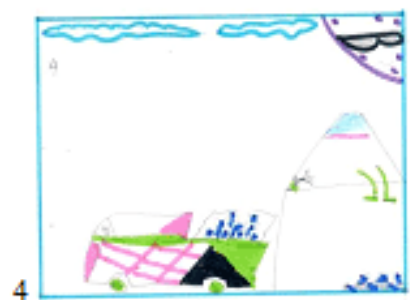

Nesse dia, o caminhão recothev o plástico e levou para onde se recicla plástico. Do plástico que foi recolhido foram fabricados vários produtos novos. Foram fabricadas sacdas para o supermercado.

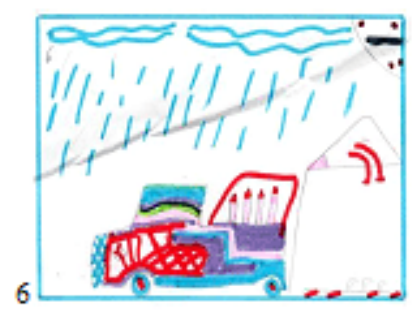

Outros produtos plásticos recolhidos do lixo foram, ainda, transformados em embalagem para pôr detergente.

Fonte: arquivo de pesquisa.

Diante disso, destaca-se que o aluno João demonstrou ter compreendido a dinâmica da reciclagem e os riscos advindos pelo descarte impróprio do lixo. É fundamental registrar que esse trabalho gerou efeitos positivos para a autoestima do aluno que, frequentemente, demonstra desânimo diante de seu insucesso no processo de 
aprendizagem dos conteúdos do currículo, pois diante da produtividade dele pôde estabelecer suas ideias e visualizar, enquanto resultado final, um material concreto produzido por ele.

Dando continuidade às atividades, aconteceu a exploração do livro "Poluição tem solução!"[9], onde foram tipificadas as diversas formas de poluição, como: do ar, da água, do solo, visual e sonora. Com o diálogo, buscou-se estimular o aluno João a reconhecer os malefícios advindos com tais contaminações.

$P: O$ que você entende que é poluição.

João: Vários lixo misturados com moscas, ratos e baratas. Faz mal, faz a gente até tossir. P: Pois é, você tem razão, a tosse é um dos muitos sintomas da poluição do ar. Além delas, lembra, tem outros tipos: do solo, dos rios e mares, do som.

P: E com toda essa poluição, como ficamos, hein? Com água, solo e ar poluídos o meio ambiente fica bem destruído.

P: A poluição vem de onde?

João: Dos homens.

João: Está acontecendo isso porque estão cortando as árvores. Podia fazer lapiseira, ao invés de lápis que gasta muitas árvores [o aluno considera tal possibilidade a fim de diminuir a derrubada de árvores para produzir produtos à base de madeira, dentre os quais, lápis].

O diálogo trouxe a reflexão da necessidade de o homem ter equilíbrio diante do consumismo, porque o que vale é o equilíbrio buscado por meio da sustentabilidade, já que a lapiseira, assim como diversos materiais necessários ao homem, é produzida por materiais de difícil decomposição no meio ambiente. 
P: Você já viu alguma pessoa que precisa de aparelho auditivo? [dialogando sobre os problemas de saúde gerados pela poluição sonora, como dor de cabeça, perda auditiva, entre outros].

João: Sim. É muito difícil falar com pessoa que não escuta, tem que falar bem perto dela.

P: É verdade, por isso a tecnologia é tão importante, como os aparelhos auditivos que são tão importantes para ajuda essas pessoas a ouvir melhor.

João: Você não viu a tecnologia? Cada dia que passa uma coisa...o que falta é criar um robô com pernas, braços, cara e sair pelo mundo. A tecnologia é do nosso cérebro [quis dizer que é criada pelo homem] e às vezes, cria coisas que não são necessárias no mundo, [o aluno se refere à criação um robô com sentimento] e um robô com sentimento não é legal, porque vai falar as coisas pra ele [dar comandos ao robô] e ele vai ficar triste e não vai fazer o que ele tem que fazer.

P: Por que você fala isso?

João: Todo ser humano tem que ter sentimento.

P: Você acha que o sentimento é importante ao ser humano?

João: Porque sem sentimento não podemos ter amigos e nem ser feliz.

Nesse caso, a tecnologia gerou no aluno João um posicionamento crítico sobre a perspectiva salvacionista da ciência e tecnologia, afirmando que, há coisas criadas que são desnecessárias ao homem, em que se depara com a falta de comunicação e entendimento entre os seres humanos.

Essa explanação das atividades se fez necessária para que pudéssemos trazer como o jogo da memória está inserido nesse momento da pesquisa. Com as ilustrações trazidas pelo livro, o aluno pôde perceber toda problemática da poluição, enquanto 
ações inconsequentes do meio em que está inserido. Assim, a partir do conhecimento adquirido, foi desenvolvido um jogo da memória com as diversas formas de poluição. $\mathrm{O}$ jogo foi elaborado com figuras oriundas de pesquisa feita na internet, o que deixou o aluno bem entusiasmado e animado pela atividade, conforme figura 3 .

Figura 3 - Jogo da memória desenvolvido junto ao aluno sob a temática poluição

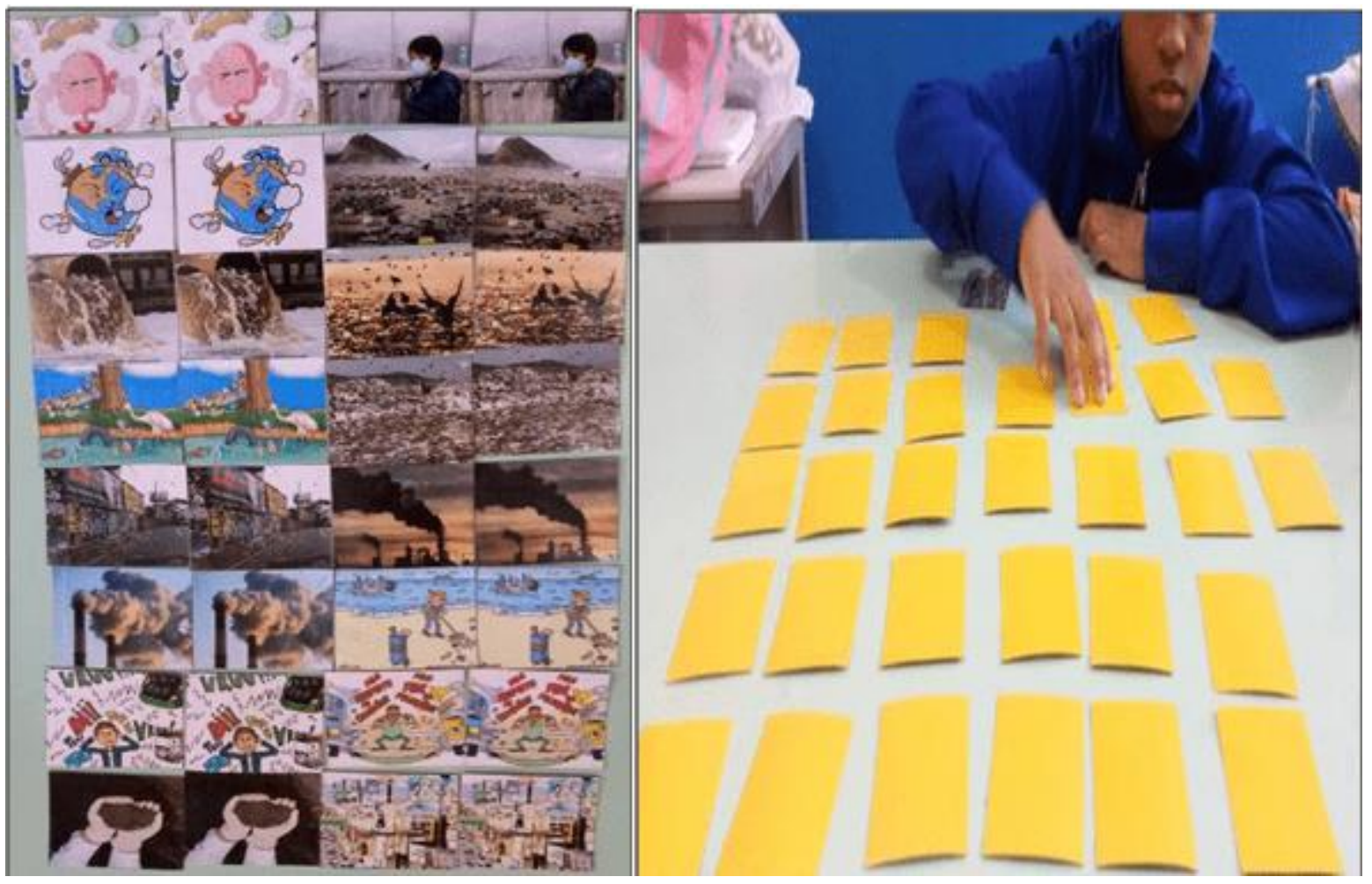

Fonte: arquivo de pesquisa.

O aluno registrou, por meio de desenho, sua impressão sobre o meio ambiente. Usou uma folha em frente e verso para fazer a comparação entre o ideal e o real. Na frente da folha, ele desenhou o que seria um meio ambiente preservado, limpo, já no verso, ilustrou o meio ambiente devastado, sem vida, caso o homem insista em não assumir sua responsabilidade de cuidar e proteger seu habitat natural. João: $O$ mundo limpinho, cheia de árvore com fruto, onde todo mundo pode viver bem. O mundo que seria bom pra todo mundo viver. Esta fala do aluno representa uma realidade que, na visão do dele, seria o ideal para uma vida com qualidade, um ambiente com sol, céu azul, com vida (Figura 4). 
Figura 4 - O meio ambiente ideal, de acordo com a concepção do aluno.

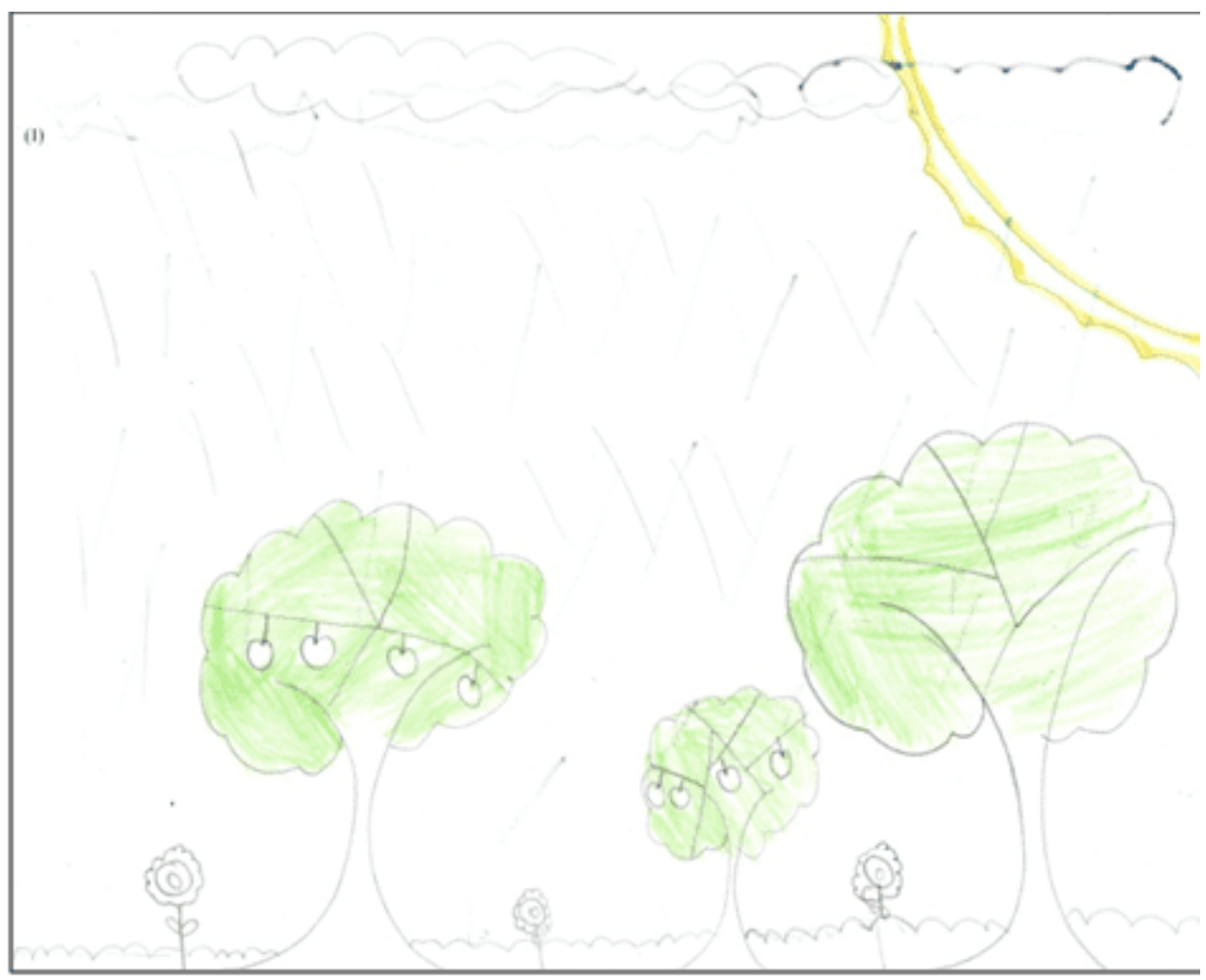

Fonte: arquivo de pesquisa.

Os jogos utilizados procuraram valorizar a funções lúdica e educativa, à medida que, sob o olhar da ação pedagógica, explorou os temas sócio científicos propostos na pesquisa e, vinculados à ludicidade foram desenvolvidos e ou adaptados de acordo com a preferência individual de cada aluno.

A apropriação do conhecimento do aluno Alisson sobre o conteúdo explorado aconteceu à medida que o aluno percebeu as consequências das atividades humanas no ambiente, onde alguns acontecimentos viram fatos históricos, alguns lugares se modificam muito, outros um pouco menos, enquanto outros se mantêm A apropriação do conhecimento do aluno Alisson sobre o conteúdo explorado aconteceu à medida que $o$ aluno percebeu as consequências das atividades humanas no ambiente, onde alguns acontecimentos viram fatos históricos, alguns lugares se modificam muito, outros um pouco menos, enquanto outros se mantêm preservados, conforme estratos dos diálogos: 
P: Por que está assim? Quem você acha que modificou?

Alisson: Os homens. Porque veio as pessoas morar pra cá. Tinha que construir casas.

P: Com o desenvolvimento do local, fale das coisas boas, em sua opinião.

Alisson: Rua de concreto [o aluno faz referência às ruas asfaltadas], lojas, escola.

P: Agora fale das coisas que prejudicam o local.

Alisson: Falta de cavalo, de mata.

Alisson: Eu queria que continuasse assim.

Alisson: Tinha fazenda, tinha cavalo, tinha mata.

A sensibilização dos alunos para os problemas ambientais é fundamental para que seja possível conscientizá-los, sensibilização essa que pode ser atingida com o auxílio do audiovisual que leva estas imagens para dentro da sala de aula (ARROIO, GIORDAN, 2006).

A proposta compreende a abordagem discursiva sobre as atitudes $\mathrm{e}$ as consequências das pessoas para a sociedade e o meio ambiente.

Em prosseguimento a esse diálogo, foram mencionadas as três ações necessárias para o processo de reciclagem: reduzir, reutilizar, reciclar, de forma que foram levantadas várias situações vivenciadas no dia a dia, como por exemplo, o descarte do lixo doméstico.

Com base nessa ideia iniciamos o diálogo, a partir da pergunta: "O que fazer com aquilo que não serve mais para você?" $O$ aluno Alisson foi orientado sobre a maneira de como separar o lixo. O aluno teve conhecimento das cores destinadas a cada tipo 
de lixo onde: verde, para vidros; amarelo, para o metal; azul, para o papel; vermelho, para plásticos; marrom, para lixo orgânico. Contudo, ainda que tenham essas cores, o recomendado é que se separe o lixo sob duas condições: lixo seco, àquele que foi separado pelas cores, e o lixo úmido, àquele proveniente de restos de comida, cascas de frutas e legumes, folhas e materiais não recicláveis. P: E então, será que tem como fazer essa separação na sua casa? Fala com sua mãe para iniciar esse processo? Alisson: É, vou falar com ela.

O aluno relatou que na rua de sua residência não há limpeza e recolhimento do lixo urbano, situação que causa incômodo em seu entorno. Alisson: Eu pego o lixo da minha casa e desço. $O$ aluno se refere aqui ao fato de ele morar na parte alta da comunidade e ter que descer algumas ruas com o lixo para deixá-lo em local em que há a coleta de lixo urbana, onde o caminhão de lixo passa para recolher. Mas é uma prática que não acontece com seus vizinhos, que depositam o lixo em locais indevidos. Alisson: Os que moram lá não faz isso, eles deixam o lixo na rua, aí, vêm os animais [cachorros, cavalos] rasgam o lixo e suja tudo, fica com cheiro muito ruim. É possível observar que o aluno tem consciência do quanto à poluição do ambiente traz aspectos negativos e interfere, diretamente, na coletividade.

Num desenho produzido pelo aluno, mostrado na figura 5, ele representa bem isso, ao passo que, ao dividir o desenho em cenas, ele explorou as agressões provocadas pela poluição ao meio ambiente. 
Figura 5 - Destino do lixo no entorno da casa do aluno Alisson.

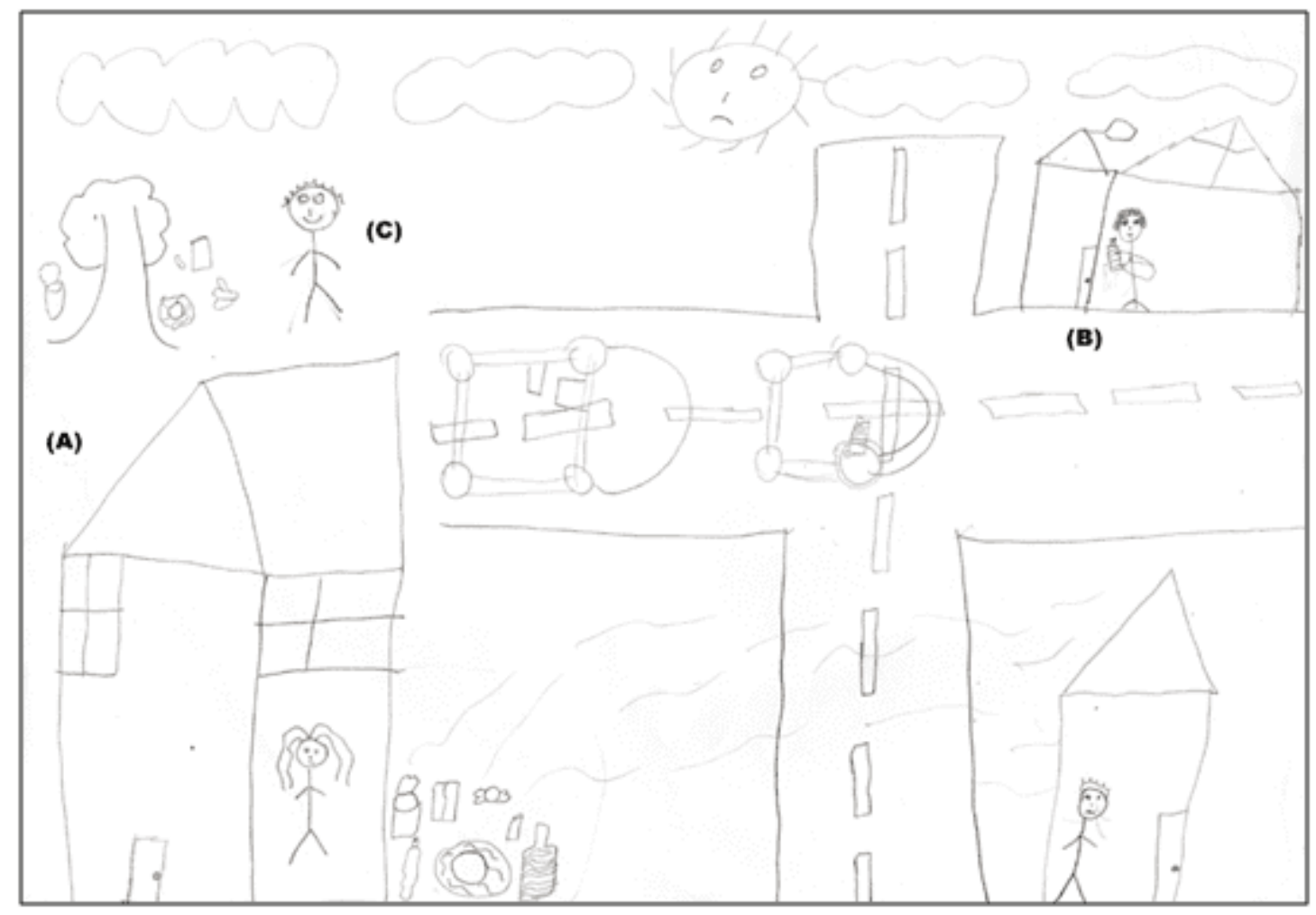

Fonte: arquivo de pesquisa.

Alisson: Aqui [apontando para o desenho (A)], a casa do lado de uma rua ela [uma figura feminina] pegou o lixo da sua casa e jogou no fundo da casa, o que causou mau cheiro na casa do vizinho e o lixo acumulou e começou a juntar bichos e incomodar a vizinha. Aqui [apontando para o desenho (B)] em outra casa pessoa joga o lixo no meio da rua, estava bebendo vinho e joga a garrafa e o carro passou e furou o pneu. Aqui [apontando para o desenho(C)], ele [figura masculina] joga lixo na árvore, lixos são jogados em seu caule [aponta para a árvore].

O aluno não comentou sobre a expressão do sol, mas como tal expressão chamava a atenção e era sugestiva diante daquelas cenas, foi the perguntado o porquê da expressão do sol, em que respondeu: Alisson: O sol fica muito triste com tudo que tá acontecendo. 
Ainda se referindo a essa condição, foi indagado se enquadrava em alguma daquelas cenas, ao que respondeu: Alisson: Não, porque não é certo fazer essas coisas.

Os cidadãos, muitas vezes, são conscientes e conhecem quais as necessidades de melhoria do seu entorno, em termos de problemas de limpeza urbana, saneamento, destino legal do lixo, situações essas, que muitas vezes são ignoradas e ou desconsideradas por especialistas, como mazelas daquela realidade social.

Por isso, é sempre importante que o professor considere as informações que o aluno já traz consigo, uma vez que os conhecimentos do senso comum serão a base para a construção de um aprendizado significativo, pois por meio deles é que os alunos chegarão ao conhecimento científico.

Dando sequência à aula, aconteceu um diálogo sobre o destino final do lixo e as consequências sociais e ambientais dessa ação, momento em que houve a citação de outras duas leis recentes que entraram em vigor com o discurso de corroborar com o meio ambiente, na tentativa de diminuir o consumo e produção de lixo plástico, já que o plástico é considerado um dos vilões do meio ambiente. São elas: a Lei no 7957/2018, de 15 de maio de 2018 (RIO DE JANEIRO, 2018a), que proíbe a utilização de canudos de plástico em restaurantes, bares, quiosques, ambulantes, hotéis e similares no âmbito do estado do Rio de Janeiro, e a Lei no 8006/18, de 25 de junho de 2018, que obriga os estabelecimentos comerciais localizados no estado do Rio de Janeiro, a substituírem e recolherem sacolas plásticas por sacolas biodegradáveis (material renovável).

Em relação à lei do canudinho e sobre pagar $\mathrm{R} \$ 0,05$ por cada sacola (a partir da terceira) o aluno demonstrou, em sua fala, qual decisão vai tomar ao ir ao supermercado: Alisson: Então é melhor levar [sacola] de casa! [Disse num tom de espanto].

Com base no exposto, o desdobramento da proposta da pesquisa com os alunos João e Alisson, contemplou uma abordagem educacional bem próxima à educação progressista proposta por Paulo Freire, cuja centralidade residem na problematização 
e na dialogicidade, à medida que apresentaram três pontos de convergência, de acordo com Nascimento e von Lisingen (2006):

i - abordagem temática e a seleção de conteúdos e materiais didáticos;

ii - a perspectiva interdisciplinar do trabalho pedagógico e a formação de professores;

iii - o papel do professor no processo de ensino e aprendizagem e na formação para o exercício da cidadania (NASCIMENTO e VON LISINGEN, 2006, p.97).

Dentro do tema meio ambiente, nos bloco de atividades, houve o debate de questões sociais, valores morais e éticos oriundos do desenvolvimento científico e tecnológico, onde, por meio da problematização, o sujeito foi levado a se deparar com uma questão de vida diária e, a partir disso, por meio de investigação, passou a conhecer "aquilo" que the era desconhecido, com o estímulo de se modificar e modificar seu contexto social.

O foco desenvolvido a partir do tema meio ambiente foi o reconhecimento do homem como parte integrante desse meio, com implicações e impactos das ações humanas na natureza; natureza essa que possui elementos essenciais à manutenção de vida na Terra e, como este planeta tem sido sequelado pelas mazelas provenientes da poluição, do lixo, do desmatamento.

As atividades foram planejadas em consonância com os interesses dos alunos, no sentido de eles apresentarem empatia e prazer em realizar e ou desenvolver. Nesse sentido, houve a promoção de diferentes formas de materialização do conhecimento: leitura de livros de histórias, pintura, diálogos, jogos educativos, produção de materiais e, com isso, os fenômenos observados ao longo do processo permearam a realidade do aluno à medida que propôs estimular várias funções, como: raciocínio lógico, atenção, linguagem, entre outras, a fim de proporcionar o aprendizado do aluno, aproximando-o de conceitos que, depois de vivenciados e experimentados possibilitaram a visualização desse conhecimento em situações do dia a dia. 


\section{APONTAMENTOS DOS LICENCIADOS-PESQUISADORES: IMPLICAÇÕES NA FORMAÇÃO INICIAL}

De acordo com Barbosa e Cassiani (2015), é importante que a docência promova um diálogo entre teoria, específica da formação de professores, e a realidade educacional atrelando teoria e prática. Quando nos referimos à prática na Educação Inclusiva, muitas das vezes, na formação do professor de Química, essa abordagem fica por conta de diálogos efêmeros em disciplinas optativas, ou simplesmente nas aulas da disciplina Língua Brasileira de Sinais (Libras), estabelecida nos cursos de licenciatura por todo o Brasil, pelo artigo terceiro do Decreto no 5.626/2005 (BRASIL, 2005).

O ensino de Química, para o segmento infantil, dentro de um cenário internacional, começou a ser pensado nos anos 60 do século passado, já indicava um movimento interdisciplinar que aproximava a criança da observação dos fenômenos, num ensino desvinculado de memorizações de nomenclaturas específicas. Nesta época, pensouse no ensino por observação, o que possibilitaria uma maior abrangência na compreensão das crianças, e por conta disso, o ensino de ciências foi direcionado aos processos químicos (MORI; CURVELO, 2014).

A Química não pode ser vista apenas como conteúdo escolar, mas deve ser entendida como um campo de vastos conhecimentos relacionados à vida em sociedade. Deve proporcionar ao cidadão a possibilidade de escolhas, daquilo que é útil e necessário, ou daquilo que pode acarretar riscos e interesses obscuros, por ser produzido cientificamente. O currículo de ciências está impregnado de conteúdos de química, desde os anos iniciais, mas muitos professores não aceitam essa abrangência. Tal fato se deve à forma reducionista com a qual os assuntos químicos são abordados em sala de aula. Muitas das vezes o termo "química" é considerado inapropriado para ser discutido junto às crianças, sendo justificado que nessa faixa etária o melhor é usar o termo "ciências", de um modo geral (JUNIOR, 2008).

Este estudo de observação, com aulas no ambiente Atendimento Educacional Especializado, possibilitou que os bolsistas pudessem ter experiências docentes em 
um ambiente totalmente exógeno aos seus locais de atuação docente em formação, que se resumem, majoritariamente, em salas de aulas regulares.

Como excertos podem-se citar trechos dos relatórios dos bolsistas ao final das intervenções:

Bolsista 1: [...] as Salas de Recursos Multifuncionais são ambientes dotados de equipamentos e materiais pedagógicos e didáticos para oferta do Atendimento Educacional Especializado, trazendo como a maior diferença entre a sala de aula regular o atendimento individual, talvez, por ser um ambiente mais privado o aluno se sinta mais livre para se comunicar e participar das atividades propostas pelo professor do que numa sala regular, a individualização do atendimento permite ao profissional ter uma visão melhor, do que a de um professor da sala regular que possui na maioria das vezes mais de 20 alunos, das necessidades pedagógicas do aluno podendo direcionar o enfoque do tempo do atendimento para ajudar da melhor forma possível.

Bolsista 2: [...] sabemos que o aluno precisa de alguma ação mais subjetiva, vimos que em sala de aula regular tal fato não é possível, por conta da sobrecarga sobre os professores, pois eles possuem geralmente cerca de 30 alunos em sala. [...]

Percebe-se que os dois bolsistas reconhecem a importância de um local que privilegie os alunos com deficiências, e fazem comparações com as salas regulares, que comumente apresentam um número acima do permitido de alunos por turma. Verificase que as necessidades devem ser tratadas com uma atenção técnica e pedagógica. Mas apesar dessa observação, um dos bolsista também inferiu que

O espaço atende às necessidades, porém, é majoritariamente dirigido por improvisações, o que mantém o lugar apto a continuar recebendo essa aula é o esforço do professor, que é obrigado a sempre se reinventar com materiais didáticos e jogos feitos com reciclagem, é 
evidente a negligência dos órgãos públicos em relação à distribuição de materiais didáticos. (Bolsista 1).

Aqui, ele faz crítica ao cenário do ensino inclusivo brasileiro, onde cabe aos docentes a responsabilidade de harmonizar todos os desafios pedagógicos alusivos à inclusão. tal observação é corroborada por Terra e Gomes (2013, p. 13):

São os professores que essencialmente carregam a árdua tarefa de conciliar, mesmo com todas as carências existentes no sistema educacional brasileiro, suas atividades a fim de satisfazer todos os seus alunos com NEE, visando transpor todas as dificuldades existentes na sua inserção e inclusão a rede regular de ensino.

Portanto, projetos como este, que apresentam foco principal a formação cidadã, com possibilidades para a criticidade, que permita a relação entre a teoria da sala de aula com os saberes aprendidos e desenvolvidos no dia a dia dos estudantes, devem ser mais desenvolvidos nas licenciaturas, pois só assim, é possível o desenvolvimento social e econômico do país, com uma educação realmente inclusiva, pública e de qualidade.

\section{CONSIDERAÇÕES FINAIS}

O Ensino CTS (Ciência Tecnologia e Sociedade), na perspectiva inclusiva, traz um embasamento significativo na construção da cidadania desses sujeitos em particular, principalmente hoje em dia, onde verificamos que o ensino de ciências tem como objetivo desmistificar a concepção ingênua de que C\&T promovem bem-estar social ao produzir artefatos que contribuem para melhorias da vida humana. Se formos por esse caminho ideológico, estaremos atribuindo que as tecnologias estão servindo para a modificação de realidades, e são totalmente excluídas de valores e opiniões, ficando a cargo da sociedade as definições e decisões do que se deve fazer com os resultados. 
Destarte, a escola, dentre outras ações, deve promover a educação inclusiva reconhecendo a responsabilidade de promover o sujeito ao aprendizado como um todo, possibilitar o acesso do mesmo a todas as áreas do conhecimento. Ainda assim, o compromisso de educar não cabe somente à Educação Especial, mas à escola e demais agentes da educação, resguardando dessa forma, o direito do cidadão de se apropriar do saber.

\section{REFERÊNCIAS}

ARROIO, A.; GIORDAN, M. O vídeo educativo: aspectos da organização do ensino. Química Nova na Escola, n. 4, p. 8-11, nov. 2006. Disponível em: < http://www.lapeq.fe.usp.br/meqvt/disciplina/biblioteca/artigos/arroio_giordan.pdf>. Acesso em: 11 abr. 2020.

BRASIL. Ministério da Educação e Desporto. Diretrizes Nacionais para a Educação Especial na Educação Básica. Brasília. 2001.

Decreto no 5.626, de 22 de dezembro de 2005. Regulamenta a Lei $\mathrm{n}^{\circ}$ 10.436, de 24 de abril de 2002, que dispõe sobre a Língua Brasileira de Sinais - Libras, e $\mathrm{o}$ art. 18 da Lei no 10.098, de 19 de dezembro de 2000. Diário Oficial [da República Federativa do Brasil], Poder Executivo, Brasília, DF, 23 dez. 2005. p. 28. [recurso eletrônico]. Disponível em: <http://www.planalto.gov.br/ccivil_03/_ato20042006/2005/decreto/d5626.htm>. Acesso em: 11 abr. 2020.

- Ministério da Educação e Desporto. Política Nacional de Educação Especial na Perspectiva da Educação Inclusiva. Brasília. 2008. . Ministério da Educação. Documento Orientador do Programa Implantação de Salas de Recursos Multifuncionais. Brasília, 2010.

. Ministério da Educação. Decreto no 7.611. Brasília, 2011. Disponível em: < http://www.planalto.gov.br/ccivil_03/_Ato2011-2014/2011/Decreto/D7611.htm >. Acesso em: 11 abr. 2020. 
. Lei Brasileira de Inclusão da Pessoa com Deficiência, de 6 de julho de 2015. Brasília, 2015. Disponível em: < http://www.planalto.gov.br/ccivil_03/_Ato20152018/2015/Lei/L13146.htm>. Acesso em: 11 abr. 2020.

. Ministério da Educação. A área de Ciências da Natureza. In: Base Nacional Comum Curricular. Brasília. 2017, 600 p. p. 321-351.

BAZZO, W. A. A pertinência de abordagens CTS na educação tecnológica. Revista Ibero Americana de Educação, n.28, p. 83-99, jan./abr. 2002.

BENITE, A. M. C; BENITE, C. R. M.; RIBEIRO, E. B. V. Educação inclusiva, ensino de Ciências e linguagem científica: possíveis relações. Revista Educação Especial, v.28, n. 5, p.81-90. Santa Maria, jan./abr. 2015. <Disponível em: https://www.redalyc.org/pdf/3131/313132931007.pdf>. Acesso em: 11 abr. 2020.

BRASIL. Ministério da Educação e Desporto. Parâmetros Curriculares Nacionais: ciências naturais. Brasília. 1997.

CORREIA, G. B.; BAPTISTA, C. R. Política nacional de Educação Especial na perspectiva da Educação Inclusiva de 2008. Revista on line de Política e Gestão Educacional, Araraquara, v. 22, n. esp. 2, p. 716-731, dez., 2018. Disponível em: <https://periodicos.fclar.unesp.br/rpge/article/view/11905>. Acesso em: 11 abr. 2020.

DEMO, P. Pesquisa participante: mito e realidade. Brasília, 1982.

DUCATTI-SILVA, K. C. A formação no curso de pedagogia para Ensino de ciências nas séries iniciais. Dissertação de Mestrado, Programa de Pós-Graduação em Educação, Faculdade de Filosofia e Ciências, Universidade Estadual Paulista Julio de Mesquita Filho, Marília, SP, 2005.

$\mathrm{ESHACH}, \mathrm{H}$. Science literacy in primary schools and pre-schools. Netherlands: Springer, 2006.

FABRI, F.; SILVEIRA, R. M. C. F.; NIEZER , T. M.. Ensino de Ciências nos anos iniciais e a abordagem CTS: uma experiência pedagógica na formação de professores. In: 
Espacios. v. 35, $\mathrm{n}^{\circ}$ 6, 2014. Disponível em: http://www.revistaespacios.com/a14v35n06/14350609.html Acesso em: 11 abr. 2020.

GLAT, R. Desconstruindo representações sociais: por uma cultura de colaboração para inclusão escolar. Revista Brasileira de Educação Especial. Marília, v.24, n. especial, 2018. p. 9-20.

JUNIOR, C. A. C. M. A abordagem química no ensino fundamental de Ciências. In: PAVÃO, A.C.; FREITAS, D. Quanta ciência há no Ensino de Ciências. São Carlos: EdUFSCar, 2008.

KISHIMOTO, T. M. Jogo, brinquedo, brincadeira e a educação. 11 ed. São Paulo: Cortez, 2008.

KIYA, M. C. da S. O uso de jogos e de atividades lúdicas como recurso pedagógico facilitador da aprendizagem. In: PARANÁ. Secretaria de Estado da Educação. Superintendência de Educação. O professor PDE e os desafios da escola pública paranaense: produção didático-pedagógica. Curitiba: SEED/PR., 2014. V.II. (Cadernos PDE). Disponível em: < http://www.diaadiaeducacao.pr.gov.br/portals/cadernospde/pdebusca/producoes_pd e/2014/2014_uepg_ped_pdp_marcia_cristina_da_silveira_kiya.pdf $>$. Acesso em: 11 abr. 2020.

KRASILCHIK, M. O professor e o currículo de ciências. (Temas Básicos de educação e ensino). São Paulo: Ed. EPU, 2012.

KRASILCHIK, M., MARANDINO, M. Ensino de ciências e cidadania. $2^{a}$ ed. São Paulo: Moderna, 2007.

LIPPE, E. M. O.; CAMARGO, E. P. O ensino de Ciências e deficiência visual: uma percepção da professora de ciências com relação à inclusão. In: Anais da X Jornada de Educação Especial: Educação Especial e o uso das tecnologias da informação e comunicações em práticas pedagógicas inclusivas. Marília: Oficina Universitária, 2010, v.1, p.1-7. 
MORI, R. C.; CURVELO, A. A. S. Química no ensino de ciências para as séries iniciais: uma análise de livros didáticos. Ciência \& Educação (Bauru) vol. 20 n.1 Jan./Mar. 2014. Disponível em: http://www.scielo.br/scielo.php?script=sci_arttext\&pid=S1516-73132014000100015> . Acesso em: 11 abr. 2020.

MUNDIM, J. V.; SANTOS, W. L. P. dos. Ensino de ciências no ensino fundamental por meio de temas sociocientíficos: análise de uma prática pedagógica com vistas à superação do ensino disciplinar. Revista Ciência e Educação, v.18, n.4, 2012, p.787802.

NASCIMENTO, T. G.; VON LINSINGEN, I. Articulações entre o enfoque CTS e a pedagogia de Paulo Freire como base para o Ensino de Ciências, Revista Convergencia, v. 13, p. 95-116, 2006.

NUNES, L. R. O. P.; BRAUN, P.; WALTER, C. C. F. Procedimentos e recursos de ensino para o aluno com deficiência: o que tem sido disseminado nos trabalhos do GT 15 da ANPED sobre estes temas? Revista Brasileira de Educação Especial, Marília, v.17, p.23-40, mai/ago., 2011. Edição Especial. Disponível em: < http://www.scielo.br/pdf/rbee/v17nspe1/04.pdf>. Acesso em: 11 abr. 2020.

OLIVEIRA, D. A. A. dos S. Abordagens sociocientíficas no contexto da horta escolar. Rio de Janeiro: Publit, 2017. Disponível em: < https://docplayer.com.br/78255216-Denise-ana-augusta-dos-santos-oliveiraabordagens-sociocientificas-no-contexto-da-horta-escolar.html>. Acesso em: $11 \mathrm{abr}$. 2020.

PALACIOS, E. M. G.; von LINSINGEN, I.; GALBARTE, J. C. G.; CEREZO, J. A. L..; LUJÁN, J. L.; PEREIRA, L. T. V.; GORDILHO, M. M.; OSORIO, C.; VALDÉS. C.; BAZZO, W. A. Introdução aos estudos CTS. In: Cadernos de Ibero-América, 2003, 167 p. Disponível em: https://www.oei.es/historico/salactsi/introducaoestudoscts.php>. Acesso em: $11 \mathrm{abr}$. 2020. 
PLETSCH, M. D. A formação de professores para a educação inclusiva: legislação, diretrizes políticas e resultados de pesquisas. Educar Revista, Curitiba, n. 33, p. 143156 , 2009.

Disponível em:

http://www.scielo.br/scielo.php?script=sci_abstract\&pid=S0104$40602009000100010 \&$ Ing=en\&nrm=iso\&tlng=pt >. Acesso em: 11 abr. 2020.

RAU, M. C. T. D. A ludicidade na educação: uma atitude pedagógica. Curitiba: Ibpex, 2007.

RIO DE JANEIRO. Lei no 7957 de 15 de maio de 2018. 2018a. Dispõe sobre o uso prioritário de canudos e copos reutilizáveis ou fabricados com produtos biodegradáveis pelos estabelecimentos comerciais na forma que menciona. Disponível em: < https://leisestaduais.com.br/rj/lei-ordinaria-n-7957-2018-rio-dejaneiro-dispoe-sobre-o-uso-prioritario-de-canudos-e-copos-reutilizaveis-oufabricados-com-produtos-biodegradaveis-pelos-estabelecimentos-comerciais-naforma-que-menciona>. Acesso em: 11 abr. 2020.

RIO DE JANEIRO. Lei 8006/18 | Lei no 8006 de 25 de junho de 2018. 2018b. $<$ https://gov-ri.jusbrasil.com.br/legislacao/594011207/lei-8006-18-rio-de-janeiro-rj>. Acesso em: 11 abr. 2020.

SANTOS, W. L. P. dos; MORTIMER, E. F. Uma análise de pressupostos teóricos da abordagem CTS (Ciência, Tecnologia - Sociedade) no contexto da educação brasileira. Revista Ensino Pesquisa Educação e Ciência, Belo Horizonte, v. 2, n.2. Jul/dez.2000.

SANTOS, W. L. P.; MORTIMER, E. F. Abordagem de aspectos sociocientíficos em aulas de ciências. IENCI - Investigações em Ensino de Ciências, v. 14, n. 2. 2009. Disponível em: < https://www.if.ufrgs.br/cref/ojs/index.php/ienci/article/view/355/222 >. Acesso em: 11 abr. 2020.

VIER, R. F. da S. Práticas pedagógicas com enfoque CTS para alunos públicoalvo da educação especial. (Dissertação). Mestrado em Ensino de Ciência e Tecnologia. Universidade Tecnológica Federal do Paraná, Ponta Grossa. 2016. 
VILELA-RIBEIRO, E. B.; BENITE, A. M. C. Alfabetização científica e educação inclusiva no discurso de professores formadores de professores de ciências. Revista Ciência e Educação, Bauru, v. 19, n.3, p.781-794, 2013.

VON LINSINGEN, I. Perspectiva educacional CTS: aspectos de um campo em consolidação na América Latina. Educação em Ciência, Tecnologia, Sociedade e Ambiente, v. 1, p. 1-16, 2007 (Edição especial). Disponível em: < http://200.133.218.118:3536/ojs/index.php/cienciaeensino/article/view/150/108>. Acesso em: 11 abr. 2020.

TERRA, R. N.; GOMES C. G. Inclusão escolar: carências e desafios da formação e atuação profissional. Revista Educação Especial, v. 26, n. 45, p. 109-124, jan/abr. 2013.

\section{APÊNDICE - REFERÊNCIAS DE NOTA DE RODAPÉ}

5. Fundamentada nos marcos legais e princípios pedagógicos, da igualdade de condições de acesso à participação em um sistema educacional inclusivo, esta legislação define a Educação Especial como modalidade de ensino transversal a todos os níveis, etapas e modalidades, que disponibiliza recursos e serviços e o atendimento educacional especializado, complementar ou suplementar, aos estudantes com deficiência, transtornos globais do desenvolvimento e altas habilidades/superdotação no ensino regular (BRASIL, 2008, p.5).

6. Atendimento Educacional Especializado compreende o conjunto de atividades, recursos de acessibilidade e pedagógicos organizados institucional e continuamente ao público da Educação Especial (BRASIL, 2011).

7. Cumprem o propósito da organização de espaços, na própria escola comum, dotados de equipamentos, recursos de acessibilidade e materiais pedagógicos que auxiliam na promoção da escolarização, eliminando barreiras que impedem a plena participação dos estudantes público alvo da educação especial, com autonomia e independência, no ambiente educacional e social (BRASIL, 2010, p.6). 
8. Esta é uma sigla utilizada por von Linsingen (2007 apud Vaccarezza, 1998) para se referir ao campo de trabalho acadêmico, de reflexões, de preocupações intelectuais, sociais e políticas em CTS, em que denomina de "estudos sociais da ciência e da tecnologia" ou "estudos de ciência, tecnologia e sociedade" (ECTS) (von LINSINGEN, 2007, p.1).

9. DOMENICO, G.; ORTIZ, A. A poluição tem solução!. São Paulo: Nova Alexandria, 2009. $24 p$.

Enviado: Abril, 2020.

Aprovado: Maio, 2020. 